Available online on 15.10 .2018 at http://jddtonline.info

Journal of Drug Delivery and Therapeutics

Open Access to Pharmaceutical and Medical Research

(C) 2011-18, publisher and licensee JDDT, This is an Open Access article which permits unrestricted non-commercial use, provided the original work is properly cited

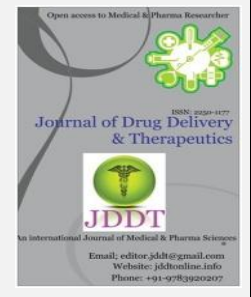

Open $\bigcirc$ Access

Research Article

\title{
ANATOMICAL STUDIES ON CORBICHONIA DECUMBENS (FORSSK.) EXELL, AN IMPORTANT MEDICINAL HERB FROM RAJASTHAN
}

\author{
Arora Sunita* and Saini Manju \\ *Prof., Department of Botany, Jai Narain Vyas University, Jodhpur (Raj.), India
}

\begin{abstract}
Corbichonia decumbens (Forssk.) Exell, commonly known as pater-chatti, is an annual or short lived perennial herb found in rocky habitats. It is used to cure kidney stone and gonorrhoea. The main objective of this study was to examine the anatomical characters of whole plant of $C$. decumbens for identification. The transverse sections of root, stem, leaf and flower have been examined and analysed. Photomicrographs were prepared with Sony HD (1920x1080/50i) digital camera. The microscopical studies revealed several interesting features viz., the presence of anomocytic stomata on both the surface; more on adaxial surface starch grains present in cortical region of root, rosette crystals in almost all vegetative parts that some time forms clusters, sclerenchymatous pericyle in stem and root presence of wide medullary rays in secondary xylem and bundle sheath around vascular bundles. The outcome showed many unique characters which may prove most important in taxonomical relevance. This study would be useful for correct identification and authentication of the plant.
\end{abstract}

Keywords: Anomocytic, Dorsiventral, Medullary rays, Bundle sheath, Rosette crystals

Article Info: Received 05 Sep, 2018; Review Completed 02 Oct 2018; Accepted 05 Oct 2018; Available online 15 Oct 2018

\section{Cite this article as:}

Arora S, Saini M, Anatomical studies on Corbichonia decumbens (Forssk.) Exell, an important medicinal herb from Rajasthan, Journal of Drug Delivery and Therapeutics. 2018; 8(5-s):228-231

DOI: http://dx.doi.org/10.22270/jddt.v8i5-s.1963

*Address for Correspondence:

Arora Sunita, Prof., Department of Botany, Jai Narain Vyas University, Jodhpur (Raj.), India

\section{INTRODUCTION}

Medicinal plants are key natural resources. Traditional and folklore medicines play an important role in health services around the globe ${ }^{1}$. Morphological and anatomical characters play a vital role in crude drug standardization $^{2}$. The morpho-anatomical structures may be directly affected by variations in the environmental conditions to which plants are exposed during developmental stages ${ }^{3}$. Correct identification and quality assurance of plant material is indispensable to ensure reproducible quality of herbal medicine, which will contribute to its safety and efficacy ${ }^{4}$. Plant anatomy basically deals with morphogenesis as it exemplifies and supports cellular and molecular structures. An approach towards correct anatomical characterization was required as literature regarding anatomy was lacking. Micro morphological characters are very important to authenticate and classify any plant as phylogenetic studies require support of variable data. Simple structures of cells and tissues may involve complex regulatory mechanisms. The anatomy is of primary importance for all aspects of research in plant sciences ${ }^{5}$. C. decumbens is an annual or short-lived herb ${ }^{6,7}$, commonly known as pater-chatti, found in rocky areas of Rajasthan. The genus Corbichonia is now placed in Lophiocarpaceae ${ }^{8,9}$.This plant shows certain typical modification to desertic conditions viz., presence of strong tap root system, expanded leaf lamina, to enhance photosynthetic area, production of light and enormous amount of seeds to bear high wind velocity ${ }^{10}$. Leaves are used as herbal alternative for healing various diseases $^{11}$. The vascular cylinder is siphonaceous and while proceeding towards a node, it elongates and gives rise to a leaf trace ${ }^{12}$. It is used as medicine for kidney stone and gonorrhoea ${ }^{13}$. Root paste is given orally thrice a day for three days in the treatment of yellow and white jaundice ${ }^{14}$. Presence of various bioactive compounds justifies the use of root and stem to cure various ailments by traditional practitioners ${ }^{15}$. The crude extract shows antioxidant, anti-inflammatory and antiulcer activities ${ }^{16}$. 


\section{MATERIALS AND METHODS}

Fresh and Disease free plants were collected from different places of Jodhpur (Beriganga, Machia Safari , Bheem-bhadak and Ossian) district of Rajasthan in the month of August. as this plant regenerates back in beginning of rainy season. This plant perennates well in unfavourable conditions of Thar Desert of Rajasthan. Preliminary specimen identification was done by Prof. PK Kasera (Head, Department of Botany, JNV Univ. Jodhpur) by consulting, "Flora of The Indian Desert" 17 and "Flora of Rajasthan" 18 for confirmation. Final authentication and identification was done by Botanical Survey of India (BSI) Jodhpur, Rajasthan. Fresh whole plant specimens were fixed immediately in FAA $(5 \mathrm{ml}$ of formalin $+5 \mathrm{ml}$ of acetic acid $+90 \mathrm{ml}$ of $70 \%$ ethyl alcohol) for $24 \mathrm{~h}$. Microscopic observations were carried out by using Olympus BX-60 microscope with 10x, 20x, 40x and 100x objectives. Handmade thin section of various plant parts was cut using microtome. Fine sections were double stained using safranin (1\% solution in $50 \%$ alcohol), fast green (1\% solution in hydro- alcohol) and glycerine was used for making temporary mounts. Photomicrographs were prepared using Sony HD (1920x1080/50i) digital camera. Special identifying features of the plant parts were studied and analysed.

\section{RESULT AND DISCUSSION}

\section{Root}

In the transverse section of the tap root pith is small as most of the space is occupied by secondary xylem, sub/ lateral roots originates from pericycle (Fig.1.a.). Secondary xylem with scattered vessels and parenchyma, well defined medullary rays are present. Vascular cambium is 5-6 layered forming secondary phloem on outer. Primary phloem is crushed. Sclerenchymatous pericycle is ruptured at some places to give space to primary phloem. Cork Cambium is 1-2 layered making multilayered parenchymatous cortex (phelloderm) on inner side and cork on outer side. Cortex is full of starch grains and crystals. Cork is multilayered and ruptured on exterior most side (Fig.1.b).

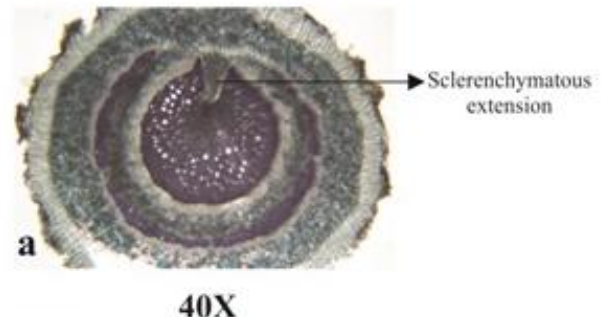

$40 X$

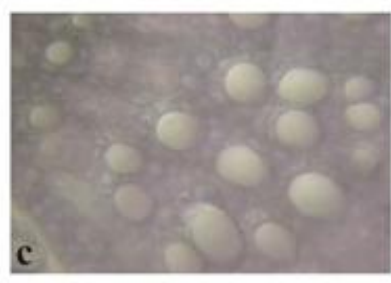

$400 X$

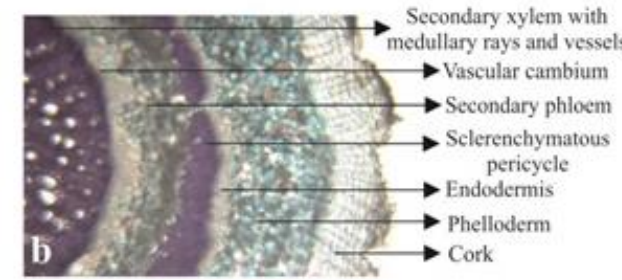

$100 \mathrm{X}$

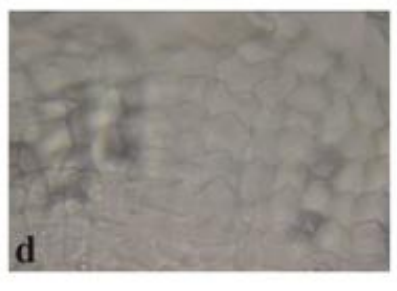

$400 \mathrm{X}$

Fig.1. T.S. of Root: (a) Sclerenchymatous extension in pith, (b) Cellular details, (c) Vessels, (d) Cork

\section{Lateral/accessory root}

Structure of lateral/accessory root is almost similar to main root, pith and sclerenchymatous pericycle is reduced (Fig.2).

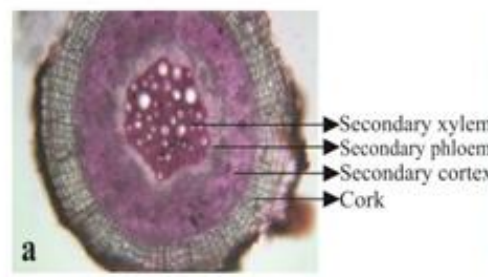

$40 X$

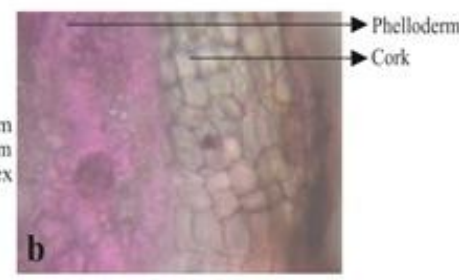

$400 \mathrm{X}$

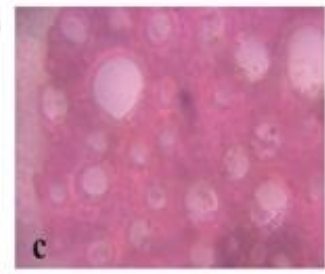

$400 X$

Fig.2. T.S. of Lateral Root: (a, b) Cellular details, (c) Vessels in Secondary xylem

\section{Stem}

Transverse section is almost circular in outline. The epidermis is continuous, single layered, covered with thin cuticle. Bulliform cells are present in between rectangular cells of normal size showing similar structure. Cortex is wide and chlorenchymatous (6-7 layered) with many rosette crystals. Endodermis is single layered; cells are barrel shaped with wall thickenings. A complete ring of sclerenchymatous 
pericycle is present surrounding vascular cylinder. Secondary xylem shows variable amount of vessels elements and xylem parenchyma. Phloem is less in amount. Cambium is 1-2 layered with ray initials and cells are isodiametric. Pith is more in amount, containing parenchyma as well as collenchyma, the cells are smaller on periphery than in centre, at certain places their wall overlaps, due to unequal diameter of cells (Fig.3.a). Rosette crystals and starch grains are also present in the pith (Fig.3.a,b).

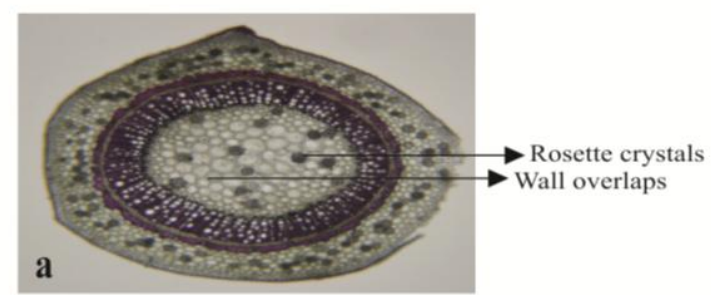

40X

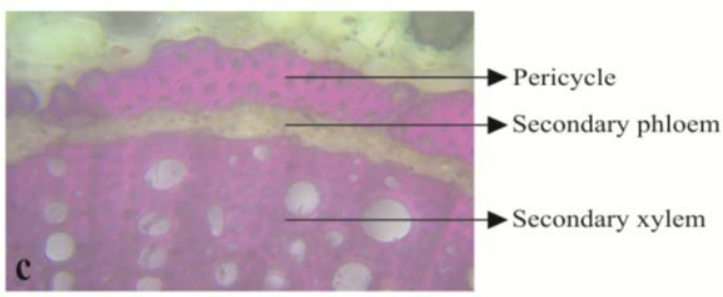

$400 X$

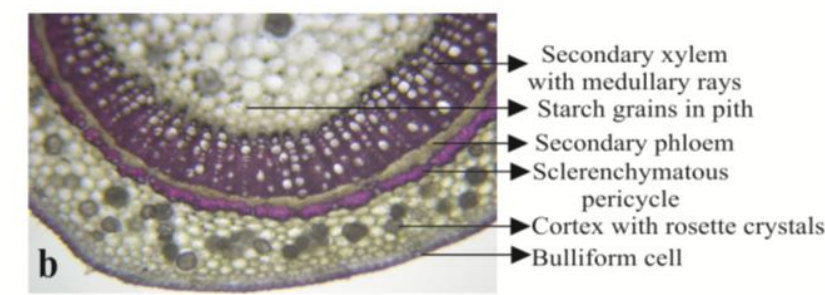

$100 X$

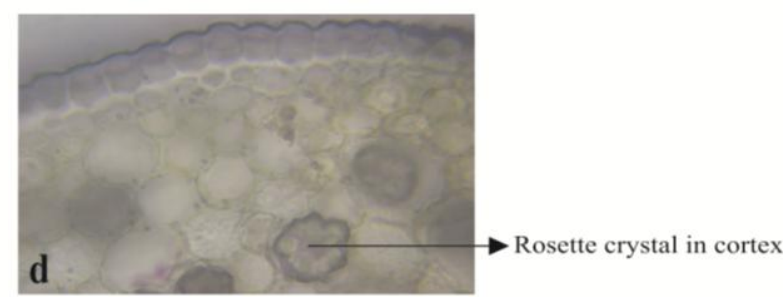

$400 X$

Fig.3. T.S. of Stem: (a, b, c): Cellular details, (d) Rosette crystals in cortex

\section{Leaf}

Dorsiventral, amphistomatic, stomata are anomocytic, more on adaxial surface. Bulliform cells are more prominent in wings region of upper epidermis. In wings upper epidermis is followed by palisade while lower epidermis is followed by mesophyll. Vascular bundles

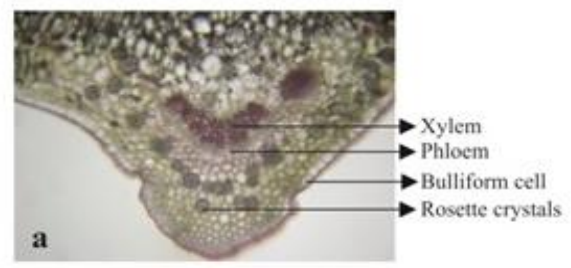

$100 \mathrm{X}$

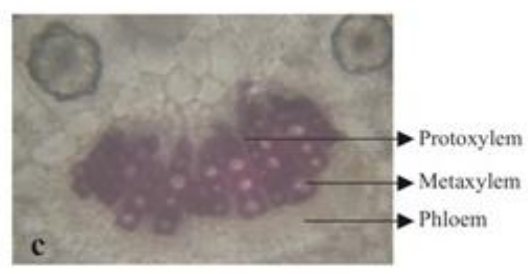

$400 \mathrm{X}$ are enclosed in bundle sheath, conjoint and collateral. Protoxylem faces upper epidermis. Phloem faces lower epidermis. Xylem shows tracheids and parenchyma. Phloem shows companion cells and parenchyma together with fibre and sieve elements. Rosette crystals are more in wings region and they are more close to lower epidermis (Fig.4).

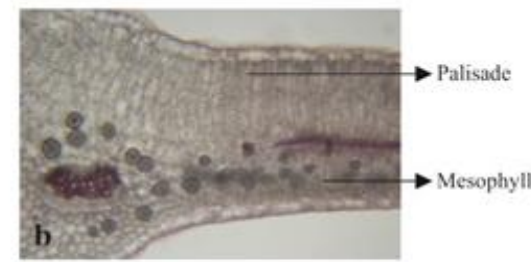

$100 \mathrm{X}$

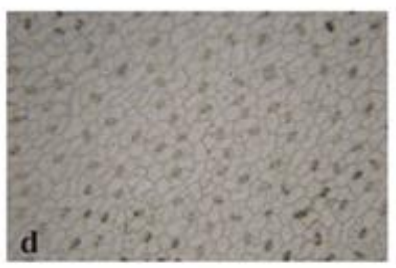

$100 \mathrm{X}$

Fig.4. T.S. of leaf: (a, b, c) Cellular details, (d) Anomocytic stomata in epidermis

\section{Flower}

Inflorescences pedunculate, terminal as well as pseudolateral, cymosely branched, many flowered, actinomorphic, hermaphrodite, hypogynous, sepals 5, polysepalous, quinquintial, petals magenta, polypetalous, stamen many, staminodes present, pink or purple, conspicuous, opposite to petals, anthers yellowish pink, ovary pentacarpellary (Fig.5) with axile placentation 2-3 ovule/carpel, stigma pentafid and style is filiform in shape ${ }^{10}$. 

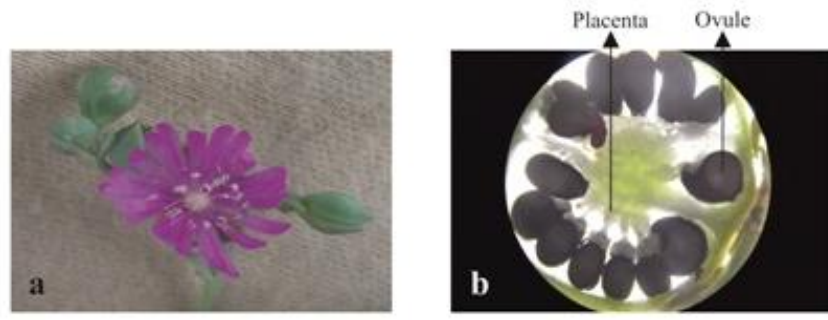

$40 X$

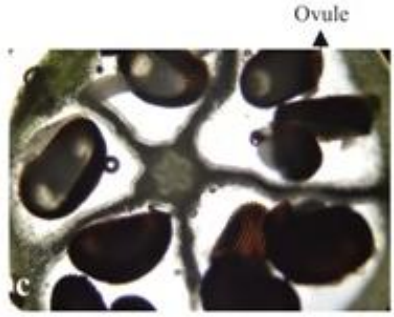

40X

Fig.5. Floral details: (a) flower, (b) L.S. of Ovary, (c) T.S. of Ovary

\section{CONCLUSION}

Anatomical studies on plants would present the fundamental details about the plant and the family to which it belongs ${ }^{19}$. Plant development may be seen as an incorporated and constant process that goes through characteristic stages or reference points often characterized by the approximation to a geometric figure. This study aims for a detailed anatomy of a medicinally important plant. We have reported pharmacognostical importance earlier ${ }^{11,15}$. Our research revealed that local and traditional people use this plant species for various purposes as medicine. This information would help in the classification of this species and contributes to its quality control and evaluation other than its proper identification and taxonomic placements.

\section{ACKNOWLEDGEMENT}

The authors are thankful to the CAS Department of Botany JNV Univ., Jodhpur(Rajasthan) for providing infrastructure and technical support.We are also thankful to Institute of Herbal Heritage,Jodhpur for assisting in microscopic assessment.

\section{REFERENCES}

1. Vedpal, Dhanabal SP, Dhamodaran P, Chaitnya MVNL, Microscopical, Morphological evaluation and fluorescent analysis of Desmodium gangeticum DC: An Ayurvedic medicinal plant. Journal of Chemical and Pharmaceutical Research, 2016; 8(7):395-402.2

2. Agarwal S, Kumar VR, Kumar A. Pharmacognostical Characterization of Ocimum spp. Journal of Pharmacognosy and Phytochemsistry, 2013; 2(1):219-224.

3. Rajni R, Vandana T, Negi KS. A comparative study of morphological and anatomical structures of four Ocimum species in Uttarakhand, India. Journal of Drug Delivery and Therapeutics, 2016; 6(6):1-6.

4. Ahmad MP, Hussain A, Siddiqui HH, Wahab S. Macroscopical, Anatomical and Physico- chemical studies of Euphorbia hirta Linn. growing widely on Eastern uttar pradesh region of India. International Journal of Biomedical and Advance Research, 2012; 3(7):541545 .

5. Presena J, Pragasam A. Evaluation of anatomical features of Adenia wightiana (Wall.ex Wight \&Arn.) Engl. of Passifloraceae for proper identification of the species. International Journal of Plant, Animal and Environmental Sciences, 2016; 6(2):132-138.

6. Forsskål P. Flora Aegyptiaco-Arabica. Möller, Copenhagen, 1775; 220pp.

7. Exell AW. Corbichonia decumbens (nomenclatural notes). Journal of Botany, 1935; 73:80-81.

8. Alexander P, Sukhorukov, Kushunina M. Taxonomy and chorology of Corbichonia (Lophiocarpaceae S.I.) with further description of a new species from Southern Africa. Phytotaxa, 2015; 218(3):227-240.

9. Thulin M, Moore AJ, Hesham ES, Larsson A, Christin PA, Edwards EJ. Phylogeny and generic delimitation in Molluginaceae, new pigment data in Caryophyllales, and the new family Corbichoniaceae. Taxon, 2016; 65(4):775-793.

10. Arora S, Saini M. Morphological studies on medicinally important plant of Gisekia pharnaceoides Linn. and Corbichonia decumbens (Forssk.) Exell of Molluginaceae from Thar Desert of Rajasthan, India. Biolife, 2016; 4(2):327-332.

11. Arora S, Saini M. Biochemical screening of leaf extract of Corbichonia decumbens (Forssk.)Exell of Molluginaceae from Thar Desert of Rajasthan, India. Advances in Plant Sciences, 2016; 29(11):275-278.

12. Bhambie S, Joshi MC, Gupta ML. Anatomical studies on certain members of Aizoaceae. Proceedings of the Indian Academy of Sciences-Section B, 1977; 85(6):399-406.

13. Katewa SS, Galav PK. Traditional herbal medicines from shekhawati region of Rajasthan. Indian Journal of Traditional Knowledge, 2005; 4(3):237-245.

14. Ram JA, Raja K, Reddy EK, Venkata RRR. Medicinal plant lore of sugalis of Gooty forests, Andhra Pradesh. Ethnobotany, 2002; $14: 37-42$.

15. Arora S, Saini M. Gas Chromatography Mass Spectrometry profiling in methanolic and ethyl-acetate root and stem extract of Corbichonia decumbens (Forssk.) Exell from Thar Desert of Rajasthan, India. Pharmacognosy Research, 2017; 9 (Suppl. S1):48-52.

16. Uma G, Balasubramaniam, Kumar VJS. Evaluation of the antioxidant activity of total phenolic and flavonoid content in Corbichonia decumbens (Forssk.) (Molluginaceae). International Journal of Pharmaceutical, Chemical and Biological Sciences, 2014; 4(1):159-163.

17. Bhandari, MM. Flora of Indian Desert. Jodhpur: MPS. Repros; 1978.

18. Shetty BV, Singh V. Flora of Rajasthan. Calcutta (India): BSI (3); 1993.

19. Patel B, Patel B, Pandya P, Harisha CR. Pharmacognostical and preliminary phytochemical evalution of Alysicarpus longifolius W. and A. Prodr, AYU, 2013; 34(2):229-232. 